\title{
The Failed Rhetoric: Presupposition Analysis on Duterte's 5th State of the Nation Address
}

\author{
Mary Ann Murillo \\ De La Salle University-Dasmariñas \\ mm11173@dlsud.edu.ph \\ https://orcid.org/0000-0001-5220-7968
}

\author{
Aiden Yeh \\ Wenzao Ursuline University of Languages \\ aidenyeh@gmail.com \\ https://orcid.org/0000-0002-3061-0438
}

DOI: http://doi.org/ 10.36892/ijlls.v3i2.587

\begin{tabular}{|c|c|}
\hline Received: & $\begin{array}{l}\text { Abstract } \\
\text { Presupposition triggers play a vital role in verbal communication. It is a }\end{array}$ \\
\hline $\begin{array}{l}\text { Accepted: } \\
\text { 06/06/2021 }\end{array}$ & $\begin{array}{l}\text { linguistic element that can be employed in utterances. Language has a } \\
\text { significant role too in the communication and interpretation of intentions by } \\
\text { analyzing presupposition in political speeches. One example of these } \\
\text { is politicians' speech, which often serves as vehicles toward achieving their }\end{array}$ \\
\hline $\begin{array}{l}\text { Keywords: } \\
\text { Discourse, State of } \\
\text { the Nation Address, } \\
\text { Political speech, } \\
\text { Presupposition, } \\
\text { Presupposition } \\
\text { trigger }\end{array}$ & $\begin{array}{l}\text { ultimate goals. This study analyzed the presupposition triggers found in the } \\
\text { President of the Philippines, Rodrigo Duterte's 5th State of the Nation } \\
\text { Address (SONA). Data was analyzed using critical discourse analysis (CDA), } \\
\text { an approach to cognitively analyze how Duterte communicated his political } \\
\text { intentions through the use of presupposition triggers. The results show that his } \\
\text { SONA was filled with propositions that were erroneous and ambiguous. One } \\
\text { example of his propositions was the frequently used lexical item "rest } \\
\text { assured", i.e., "Rest assured that we will not dodge our obligation to fight for } \\
\text { human rights." This highly contentious statement pertains to the killings and } \\
\text { his war on drugs, and other human rights violations that his government is } \\
\text { being accused of; a recrimination which alludes to the fact that the human } \\
\text { rights crisis in the Philippines has heightened, if not worsened ever since he } \\
\text { took office. This study concludes that the study of presupposition enhances } \\
\text { the comprehension of what is being communicated, particularly in political } \\
\text { speeches where failed rhetorics could also reflect a failed state. }\end{array}$ \\
\hline
\end{tabular}

\section{INTRODUCTION}

One of the powers of language is to transport the messages or information from the speaker to the receiver (Levinson, 1983). In order for the receiver to interpret what a speaker means in a particular context, one has to understand the utterances being made; And using presuppositions, how they are applied or even manipulated can contain illocutionary messages that affect the overall impact of what is being communicated. Yule (1996) emphasized that presupposition is achieved using words, phrases, and structures called indicators of potential presupposition. Concisely, the presupposition is defined as an assumption that is shared by the speaker to the listener. In some propositions, potential presupposition may occur, and it is triggered by some part of an utterance, such as a subordinate clause (Yule, 1996). In this regard, utterances joined by subordinate clauses may 
have two meanings. Further, it has been found that presuppositions are typically generated by presupposition trigger or the use of lexical items or linguistic constructions (Liang \& Liu, 2016) that reinforce the meaning of an utterance (Levinson, 1983, Huang, 2007).

Through the use of presupposition, the speaker may well impose on the receiver's interpretation of facts and events to establish positive or negative feedback on the utterances. In the context of political discourse, this ingenious play of words and various linguistic devices can help politicians gain the support of their followers. The effective application of presuppositions may contribute to the realization of the receiver's understanding of the politicians' political goals and plans for the country. Balogun (2018) stressed that there is a strong bond between language and politics, and it is derivable from the association of language and communication. She added that the language of politics is being reflected from lexicalizing or grammaticalizing linguistic behavior. Therefore, the language of politics is exercised to gain and keep power. Lakoff (1990, cited in Balogun, 2018, p.65) hypothesized that "language is politics, politics assigns power, and power governs how people talk and how they are understood". In this light, Liang and Liu (2016) proposed the use of presupposition in interpreting political speeches because it has been used as a property of language to mold the listener's ideology.

There are several studies on presuppositions in political speeches, journalism, advertising, and films. Liang and Liu (2016) studied the campaign speech of Hilary Clinton and found out that presupposition plays a vital role in strengthening important information, making language more economical and vivid, motivating the interaction with the audience and drawing a closer relationship between the speaker and the audience. Correspondingly, Zheni (2019, p. 51) interprets Clinton's speech as a revelation of her "perceptual and conceptual worlds, in which Clinton plays a language game by deceptively bestowing knowledge as factive to influence her audiences and promote her government plan". Balogun (2018) also analyzed the inaugural speech of Donald Trump. Her study revealed that Trump presupposes the uniqueness of the event in terms of the socio-economic crisis bedeviling America with an authoritative and urgency of the need to reclaim his political desire. Likewise, Al-Zubeiry (2020) looked at the presupposition found in English Newspapers Opinion and disclosed that presupposition triggers help speakers and writers pass a lot of information to their audiences to set the background of their negotiation for better and effective communication, and to mold the ideologies of their audiences. In Ge's study (2011), she theorizes that there are pragmatic functions of presupposition found in advertising, and most of them are in social context, such as euphemism, persuasion, enlargement, emphasis, and self-protection. Khalil's (2017) research revealed that presupposition served as a bridge between writer and the audience to understand the utterances given by the characters in a film. He postulated that to have a common assertion and to achieve success in communication, two or more people must assume the same interpretation based on the speaker's message. Thus, an analysis of presupposition is important to link the gap between the speaker and the audience for them to achieve a common ground in the communication process. Zheni (2017, p.29) expounded that "common ground concept is closely related to knowledge, beliefs and presupposition,". Zheni furtherly clarified that common ground is people's communal knowledge in a certain communication setup where communicators know the contextual of the event. In addition, Kroeger (2018) argued that presupposition is linguistically encoded through common ground. Hence, speakers and interpreters must share this common solid ground, or both must be on the same page of understanding utterances.

\section{LITERATURE REVIEW}

\subsection{Presupposition}

The conceptual framework of this study was grounded on Yule's (1996) seminal work on presupposition, in particular the symbiotic relationship between two propositions. Similar 
to philosophy of language, an immediate inference can be made that if one proposition is true, the other must be false. Yule claimed that presupposition serves as a link between two utterances: the presumption of truth and deniability of the claim being made. Thus, he asserted that presupposition is a strategic maneuver in expressing the speaker's arguments for a particular stance, and therefore, one should aim at understanding the meaning of the utterance and not on the sentence itself. Presupposition triggers can be creatively crafted using different linguistic forms, which he categorized into six types. Each type has different forms of presupposition triggers listed in the table below.

Table 1. Adapted from Yule's six types of presuppositions (1996, pp. 26-30)

\begin{tabular}{|c|c|c|}
\hline Types of Presuppositions & $\begin{array}{l}\text { Forms of Presupposition } \\
\text { Triggers }\end{array}$ & Examples \\
\hline \multirow[t]{2}{*}{ 1.Existential presupposition } & definite description & A, an, the \\
\hline & possessive constructions & His, hers, my, our, their... \\
\hline 2. Factive presupposition & factive verbs & $\begin{array}{l}\text { aware, realize, know, prove, glad, odd, be } \\
\text { sorry, regret, appreciate, saw } \\
\text { agree, make sense, amuse, bear in mind }\end{array}$ \\
\hline \multirow[t]{6}{*}{ 3. Lexical presupposition } & implicative verbs & $\begin{array}{l}\text { to avoid, manage, forget, happened to, } \\
\text { ought to, intend to }\end{array}$ \\
\hline & $\begin{array}{l}\text { change of state verbs / } \\
\text { aspectual verbs }\end{array}$ & $\begin{array}{l}\text { stop, resume, continue, begin, given up, } \\
\text { finish; take; leave; enter; come; go; arrive; } \\
\text { change, cease }\end{array}$ \\
\hline & verbs of judging & criticize, praise, accuse \\
\hline & conventional items & $\begin{array}{l}\text { not restricted to verbs only; lexical items } \\
\text { with conventional meaning; nouns that } \\
\text { carry conventional meaning }\end{array}$ \\
\hline & focal adverbs & even, too, only \\
\hline & iteratives & $\begin{array}{l}\text { to, again, to return, another time, to repeat, } \\
\text { for the ninth time, anymore; to come back, } \\
\text { restore, repeal, reestablish, }\end{array}$ \\
\hline \multirow[t]{5}{*}{ 4. Structural presupposition } & Cleft constructions & It - cleft; wh- cleft; by cleft \\
\hline & Adverbial clauses & $\begin{array}{l}\text { Temporal clauses - before, while, since, } \\
\text { after, during, whenever, when, as.. }\end{array}$ \\
\hline & Comparative constructions & $\begin{array}{l}\text { (Adjective-er }+ \text { than }) \text { and (As }+ \text { adjective }+ \\
\text { as) }\end{array}$ \\
\hline & $\begin{array}{l}\text { Restrictive relative clauses } \\
\text { Non-restrictive clauses }\end{array}$ & $\begin{array}{l}\text { who, which, what, that } \\
\text { with dependent clauses; with relative } \\
\text { pronoun }\end{array}$ \\
\hline & Questions & interrogative forms; rhetorical questions \\
\hline 5. Non-factive presupposition & something that is not true & imagine, pretend, dream, wish \\
\hline 6. Counterfactual presupposition & $\begin{array}{l}\text { Counterfactual } \\
\text { conditionals }\end{array}$ & if-clause; contrary to the facts \\
\hline
\end{tabular}


Presupposition is represented with this symbol $>>$, and the detailed explanation for the six types of presuppositions taken from Yule (1996) are as follows.

\section{Existential Presupposition}

It is the assumption assumed to be committed to the existence of the entities named by the speaker and assumed to be present in the noun phrase.

\section{Example:}

Mary's bag is new.

$>>$ We can presuppose that Mary exists, and she has a new bag.

\section{Factive Presupposition}

It is the assumption that is true and can be identified by verbs listed above (table 1), for example know and realize. The message that is given by the speaker comes after a factive verb/construction signifying or validating (a) fact. The verbs know and realize trigger factive presupposition that imply propositions which cannot be questioned.

\section{Example:}

I know it's over.

$>$ We can presuppose that something is already finished or over.

\section{Lexical Presupposition}

The speaker asserted word meaning that will be interpreted with presupposition into another non asserted meaning by the recipients. For example, the verb managed in table 1 , when used by a speaker as he did something manageable, the asserted meaning is that he succeeded in doing something. However, when someone said, 'did not manage', the asserted meaning is that the person did not succeed. In both cases, there is a presupposition (nonasserted) that a person 'tried' to do something. Some examples of lexical presupposition that is common in political speeches are the verbs of judging. Fillmore (1969) listed the essential kinds of verbs of judging, and these are as follows; criticize blame, disapprove, chide, scold, and reproach, accuse charge, censure, denounce), condemn and convict.

In the case of lexical presupposition, the speaker's use an expression to presuppose another (unstated) idea, whereas in the case of factive presupposition, the use of a certain expression presupposes truth that is stated after it.

\section{Example:}

You are late again.

$>>$ We presuppose that someone was late before. In this sense, we used the expression "again", which is taken to presuppose into another meaning of a particular utterance.

\section{Structural Presupposition}

In this presupposition, some sentences are considered conventionally and regularly presupposing certain parts of the structure which is assumed to be true. This type of presupposition signifies the listeners to believe that the message given is true, rather than presupposing that the person is just asking a question.

\section{Example:}

When did Mary go to Georgia?

$>$ We presuppose that Mary travelled. In this case, wh-form is known to be an assumption associated with a certain word.

\section{Non-factive presupposition}

This information is assumed not to be true. Like the given examples in table 1, 'dream', 'imagine', and 'pretend', are used with the presupposition that what follows is not true.

Example: 


\section{I dreamed that I was in Canada.}

$>$ We presuppose that someone aspired or desired to be in Canada, and we classify this kind of utterance as not true.

\section{Counterfactual Presupposition}

This presupposition means that what is presupposed is not only true, but also opposite of what is true, or contrary to facts. A conditional structure of this type is called counterfactual conditionals. This means that the presupposed information is in 'if-clause', and it is not true at the time of utterance.

Example:

If I were you, I would not do this.

$>>$ We presuppose someone is telling you not to do something. This kind of utterance is classified as not true because of the condition of "if-clause."

\subsection{Critical Discourse Analysis (CDA)}

Peter, Mukuthuria and Muriungi (2016) posit that Critical Discourse Analysis (CDA) is "usually based on power, and this can be social power of groups or institutions. Power exists if individuals are able to control the actions and thinking of others" (p.159). Moreover, critical discourse analysis concentrates on the discursive strategies that legitimize control, or naturalize social order, especially inequality (Fairclough, 1992). Politics being a social domain has practices that are discursive. Discourse in political speeches is not just about meaning in a text or an utterance, but it is also about thorough analysis of meanings that can be decoded from a text or an utterance (Widdowson, 2004). Political speeches of individuals are considered discursive practices. Thus, it is necessary to look into the occurrences of these discursive practices as an exercise that characterizes the world by demonstrating, creating, and assembling meaning (Fairclough, 1992). One way to look into these discursive practices in political speeches is through analysis of presupposition. According to Peter, Mukuthuria, and Muriungi (2016) presupposition can be used as a discursive and cognitive category of analysis by looking into discursive practices as indicator of power, dominance, beliefs as true even if they were not known by the listeners or audiences.

\subsection{Political Discourse of Presupposition}

Van Dijk (2005) explained that "semantic macropropositions may observe the relevant (semantic) participants in particular propositions. The predicates of semantic macropropositions also show some preferences" (p. 25). Given the prominent role of political actors, it is expected that political events and actions such as what politicians have done or will do and what they will decide or which opinions they have about political issues are part of their speeches. Van Dijk (2005) posits that "the predicates of the macrostructures of political discourse tend to be future-oriented." (p.26), and they relate to future events or issues in references to or threats about future developments, announcements or promises about future actions and so on. Hence, politicians most of the time sound rhetoric and promising in their messages. "The macro propositions (topics) of political discourse may typically be modalized semantically, i.e., with modality 'operators' that modify propositions" (Van Dijk, 2005, p. 26- 27). In addition, political language is mostly analyzed through lexical choice and variation, syntactic categories, semantic and pragmatics style. Interpropositional relations of political discourse are coherent to conditional and functional relations. Conditional relations are often of the causal or temporal kind, while functional relations are often general expressions, specific expressions, contrasts, examples of stories, and rhetorical nature. Conditional relations are makers like 'if', that serves as a face-saving tactic during an incident (Cheng, 2002). For instance, if you apologize, you're accepting your mistake. Meanwhile, functional relations are proper discourse functions for independent sentences, and they cannot usually be reduced to clausal relations within compound sentences (Van 
Dijk, 1989). In order to explain or specify earlier information, it requires turn boundaries in the conversation. For instance, Mary is sick, and she has flu, this statement cannot be functional because there is no causal relationship. The proposition must be Mary doesn't come, because she is sick. Based on the given examples, both conditional and functional relations are causal. Therefore, these two concepts are indeed intertwined to interpropositional relations of political discourse, and have important roles in acquiring the social meaning of utterances.

Understanding social power and dominance are important in Critical Discourse Analysis (CDA), because these are considered as crucial presuppositions of CDA (Van Dijk, 1996). Thus, context, especially political context is important for us to observe how speakers act in the society (Fairclough, 2012). One way to comprehend the political context of an individual is to have a mental representation about the person (Van Dijk, 1996). Van Dijk furtherly explained that context usually controls not only what is being said but how it is said.

Another concept that exists in presupposition is negation, and this may happen through the following triggers - using not, perhaps, if-condition, and questions (Yule, 1996). Likewise, Van Dijk (2005), described that political language can be analyzed through negation as well. He called it apparent negation and apparent concession. An example of this is when the speaker says, "I have nothing against Black, but..." (apparent negation), "There are also smart Blacks, but I still don't like them as my boss." ... (apparent concession) (p.32). Furthermore, politicians incline themselves and their own group in an optimistic way. They tend to describe others negatively to positioned themselves in good impression and put the liability to their opponents (Van Dijk 1996). Hence, this signifies a discourse of racism. According to Van Dijk (1989), discourse or racism can be determined in the syntactic structures of sentences through word order or the use of active or passive constructions. He added that the responsible agent of an action is usually referred to with the expression that is a syntactic subject of the sentence, and that occurs in first position. Word order may signal how speakers interpret events, that is, what their mental models of such events look like. Among other things, word order may express the role and the prominence of underlying meanings. The concept of apparent negation is often semantically restricted to contradictory opposition between propositions, while apparent concessions are conditional acceptance of the first proposition (Van Dijk, 2005). Van Dijk (1989) also explained that the term 'apparent' is used because the first proposition is a positive part that primarily functions as a form of face-keeping and impression management, and the rest of the text or fragment will focus on the negative characteristics of the others. Thus, contradicting happens for the first positive part of the utterance.

Language use in concession speeches among politicians is very common (Anurudu \& Oduola, 2017). Certainly, Peter et al (2016) emphasized that supremacy existed in political speeches and it is created through other discourse elements; stereotypes, implicature, hate, verbosity and presupposition. Furthermore, apparent statements of power are aspects of discursive signals used by elders to have mutual authority in the conversation. This is similar with the usual implied explanation used by the government speakers when responding to questions given to them. They used this strategy consciously to achieve their desired goals in the communication. Therefore, politicians feel that language is a power, and they always want to be felt not only by the people they serve, but also by their fellow politicians. This is similar to the idea of Zheni (2020) about Donald Trump's political discourse, in which she rationalized that speech acts are often used in political speeches as an approach to achieve one's purpose, and she concluded that Trump's language usually dictates, commissive in form, and express subliminally in expressive speech acts.

\subsection{Previous Studies}

Political speech was chosen in this study to show the connection of various linguistic devices and social incitement in interpreting utterances. Presuppositions used in presidential 
speech can offer comprehension to political actors in delivering their information and can help the listeners to deepen their understanding of the given messages.

Some studies on political discourse analysis have been done by several researchers through analyzing President Duterte's platforms. One of these is about the early Duterte Presidency in the Philippines (Teehankee, 2016), in which he briefly explained the political background of Duterte. According to him, Duterte has a historical blowback against US imperialism, and he is repudiating the liberal reformist, albeit being elitist.

Teehankee and Thompson (2016) also examined early Duterte presidency from various perspectives, and they mentioned that Duterte has been labelled the "Donald Trump of the East". Szilágyi and Thompson (2016) also state, "Like Trump, Duterte's off-colour comments did not stop his poll numbers from rising but were instead seen as part of his tellit-like-it-is political style. Duterte still speaks like a tough-talking local mayor (a label which, despite now being president, he still often uses when referring to himself). He also uses expletives when referring to foreign officials or foreign governments or entities" (p. 4). They all concluded that this style is an offensive and vulgar type of communication.

Utari (2017) studied the political discourse of Duterte's drug war policy and revealed that President Duterte inclines to be drawn in bad representation because the media continuously expose his bad sides. In contrast, Thompson (2016) brought up that Duterte's fight against illegal drugs going from a lower-level concern to the top national priority in Pulse Asia opinion polls surveys of January, February and April 2016 because this concern was overtaken by other concerns such as poverty, jobs, inflation, and corruption.

With the findings mentioned above, the present study would like to see if Duterte's communication style can be interpreted clearer through the analysis of presupposition triggers using latest speech.

\section{METHODOLOGY}

Since this study focused on the analysis of the types of presupposition, their triggers, and the interpreted presupposition's social function found in the 5th SONA of President Duterte, qualitative and quantitative methods were applied in this study. Additionally, the qualitative method focused on discourse analysis of the text, while the quantitative method focused on counting the frequency of the types and triggers of presupposition used. The researcher used $\%=\mathrm{f} / \mathrm{N}$ x 100 as a formula to compute the frequency distribution of the data.

The 5th State of the Nation Address (SONA) of President Rodrigo Duterte was delivered/made last July 27, 2020 and lasted for 1 hour and 20 minutes; the speech has a total 197 paragraphs and 514 sentences. The researchers looked into each paragraph to grasp the presupposed meaning of the speaker. However, there are paragraphs that involve more than one presupposition triggers, which gives a total of 199 presupposition occurrences The data were analyzed thoroughly by doing critical discourse analysis. There were ome procedures which had been done in conducting this study. First, classifying presupposition based on presupposition triggers, and specific type of presupposition based on Yule's (1996) theoretical framework. The coded data was the initial coding or open coding (Creswell, 2007; Merriam, 2009). Second, identifying the functions of presupposition using the political discourse analysis of VanDijk (2005). Afterwhich, the social meaning of what the speaker presupposes were determined. Elaborated by related literature, the next step was selecting themes. Categories to provide the major themes were then identified. This is now the axial coding, a process of classifying initials; integrative memos were processed to clarify and link analytic themes and categories from the analysis to the related literature and theoretical framework. These data analytical techniques were introduced by Creswell (2007) and Merriam (2009) which were directed to answer the research questions. Lastly, subject to knowing the dominant presupposition found in the SONA, counting the types of 
presupposition in percentage to get the frequency distribution was done. The data were exhibited in the form of tables which were followed by descriptive analyses.

\section{RESULTS AND DISCUSSION}

This paper is only limited to the analysis of the six types of presupposition based on Yule's theory and restricted to the 5th SONA of President Rodrigo Duterte that was delivered last July 27, 2020. Its main focus is the interpretation of the most frequently used presuppositions based on their social functions.

\section{Presupposition in SONA}

The $5^{\text {th }}$ SONA of President Rodrigo Duterte used all the six types of presupposition existential, lexical, factive, counterfactual, structural, and non-factive. The symbol " $>>$ " is used to stand for "presupposes". This will be seen in the succeeding excerpts from the SONA below. Among these six, the most frequently used is the lexical presupposition. Items like, 'manage', 'stop', 'start', and 'again' are examples of lexical presupposition (Yule, 1996). Since this type of presupposition is the most frequently used, this indicates that President Duterte almost prefers using lexical items in delivering his speech to his listeners. In line with this, AL-Smaihyeen and Abdul Latiff (2018) claimed that political speeches are to be more effective and impressive when lexical presuppositions are used. It gives strong evidence that the speaker has knowledge, and the ability to convince others in his/her opinions. Also, they found out that a politician has the ability to affect listeners because of impressive speech. Further, they concluded that lexical presuppositions could convince others about certain issues. Peter et al (2016) ascertained in their study that politicians are sustained by persuasive or manipulative use of language, and such language was actualized in discourse elements as presupposition.

Table 2 shows the frequency distribution and percentage for each type of presupposition.

Table 2: Frequency distribution and percentage of each type of presupposition

\begin{tabular}{clcc}
\hline No & Type of Presupposition & Number & Percentage \\
\hline 1 & Existential Presupposition & 28 & $14 \%$ \\
2 & Lexical Presupposition & 87 & $44 \%$ \\
3 & Factive presupposition & 40 & $20 \%$ \\
4 & Counterfactual presupposition & 4 & $2 \%$ \\
5 & Structural presupposition & 32 & $16 \%$ \\
6 & Non-factive presupposition & 8 & $4 \%$ \\
& TOTAL PRESUPPOSITION & 199 & $100 \%$ \\
\hline
\end{tabular}

Table 2 above shows that 'lexical presupposition' is the most used type of presupposition trigger in the SONA with 87 occurrences $(44 \%)$ out of the total number of paragraphs (199). 'Factive' presupposition comes next with a total of $40(20 \%)$. Next is the 'structural presupposition' with a total of $32(16 \%)$ occurrences. Then, 'existential presupposition' is the 4 th

with $28(14 \%)$ occurrences, and the 5 th is the 'non-factive presupposition with only 8 (4\%) appearances. The type of presupposition with the lowest occurrences is 'counterfactual' with $4(2 \%)$.

Each type of the presupposition triggers will be described and exemplified with the excerpts below. Only the selected utterances will be shown as an example for each type. 


\section{Existential Presupposition}

According to Yule (1996), existential presupposition is assumed to be present in possessive constructions, but more generally in any definite noun phrase.

\section{Excerpts:}

(1) My countrymen, it is sad that while the government focuses its attention and resources to battle the coronavirus, there are those who take advantage of a preoccupied government.

$>>$ directed to Filipinos using the pronoun "My"

(2) The Malasakit Centers Act has proven to be of great help to our less fortunate hospitals.

citizens needing medical services through a one-stop platform in government

$>$ message is specifically directed to the Malasakit Centers Act

Based on the analysis of the study, it is found that only 28 utterances occurred as an existential presupposition in the SONA. By using an existential trigger in the sentence, the writer delivers certain presupposed messages. The possible presupposed message for example (1) is $>>$ the president directly addresses his fellowmen about his sadness on coronavirus, as well as his disappointment to those people in the government who are taking advantage of the current situation. In the second example (2), presupposed a message which is $>>$ the speaker emphasizes the great help of the Act to the citizens. As seen in the above utterances, the speaker uses the possessive pronoun "my", and "the" as a definite article. By using any of such expressions, President Duterte is assumed to be committed to the existence of the entities named and made his utterances very specific.

\section{Lexical Presupposition}

Items, like, 'manage', 'stop', 'start', and 'again' are examples of lexical presupposition (Yule, 1996). Lexical presupposition uses one form with its asserted meaning.

\section{Excerpts:}

(1) Frontline processes, including consular services, processing of building and business permits, and services for overseas Filipinos and seafarers were streamlined. Passports and drivers' license validity were lengthened to ease the burden of the public.

$>>$ to ease, to avoid, or to manage the burden for Filipinos

(2) Rest assured that we will not dodge our obligation to fight for human rights.

$>>$ assures to manage the responsibility on human rights

(3) One of them is Senator Frank Drilon. In an interview, he arrogantly mentioned among others that oligarchs need not be rich. Then he linked the anti-dynasty system with oligarchy and the topic was my daughter and son. This happened after the Committee on Franchise voted 70-11 to deny the grant of franchise to ABS-CBN. Obviously, he was defending the Lopezes that they are not oligarchs.

$>>$ referring to a specific person, pointing to Senator Frank Drilon, a senator and a lawyer-He has served as the Senate Minority Leader since 2017.

(4) Let me say that the strength of a nation rests in the hands of the people acting as one with government, in the pursuit of common goals and objectives.

$>>$ iterated, emphasized or stressed out the strength of the nation. 
In the given examples above, it is very evident that the speaker put affirmation on his messages by saying "to ease the burden ..." (example 1), and "rest assured..." (example 2). Lexical presupposition appeared to be the topmost used in the SONA. This indicates that the speaker almost prefers using lexical items in guiding his listeners to arrive at his implied messages. In example (3), the speaker pointed out a specific person. This was triggered by the noun phrase "one of them". According to Fillmore (1969) one of the examples of verbs of judging is justifying. In the statement of the speaker, he emphasized the verb of judging "defending" by modifying it with the adverb "obviously". Fillmore added that verbs of judging are considered as an attitude of the communicator that involves different factors judge, defendant, affected or addressee, and situation. Lastly, in the given example (4) the speaker is emphasizing, iterating, or stressing out that the country's strength relies on those who can cooperate especially the ones seated in the government. In this example it was triggered by a verb phrase "let me say", which led the listeners to draw the implicit idea asserted in the statement. Liang and Liu (2016) mentioned that iteratives are verbs or adverbs that indicate "reestablishing" an utterance.

\section{Factive Presupposition}

Yule (1996) claimed that factive presupposition can be triggered by using a verb like 'know' and it is treated as a fact. Other verbs such as 'notice', 'realize' and 'regret' as well as phrases involving 'be' with 'aware', 'odd' and 'glad' have factive presuppositions.

\section{Excerpts:}

(1) In this regard I would like to express my gratitude to all those who made possible the steady supply of food, water, and basic utilities [to] our households [applause] and the provision of basic social services and financial assistance to our people. Our profound gratitude goes to everyone who helped country food supply chain running, the valiant soldiers, policemen and security guards who kept peace and order [applause] in our communities; the dedicated personnel who kept our essential establishments operational. You showed us kindness and selflessness. You gave us strength. You risked your own lives to serve the greater good in keeping with the Filipino spirit of Bayanihan. [applause]

>> implies gladness to those who helped the country

(2) Let me also recognize the efforts of the local government units that stepped up and initiated their own response measures to contain the effects of COVID-19 and its impact to their constituents. Have been - impact to its constituents. [The shadow says it's a period there.]

$>>$ notice and appreciate the efforts of local government units

In example (1), the speaker clearly stated that he is expressing his gratitude, and even emphasized in the succeeding statement that he is voicing out his profound gratitude. The presupposed meaning of this is $>>$ glad. In the second example (2), the speaker mentioned the verb recognize which has a presupposed meaning of $>>$ notice or appreciation. Factive presupposition occurred 40 times in the SONA.

\section{Counterfactual Presupposition}

According to Yule (1996), "A counterfactual presupposition refers to the case that what is presupposed is not only 'not true' but is the opposite of what is 'true', or 'contrary to facts." (p.29). He adds that there are conditional structures, generally called counterfactual conditionals, which presuppose that the information given in the If clause is erroneous, inaccurate, and therefore, misleading (p.29).

\section{Excerpts:}


(1) If we allow greed, self-interest and ambition to rule us, then as stated by one prominent physician, we will - be left with nothing better than the lesser evil instead of the greater good

$>>$ if-condition on choosing between lesser evil versus greater good

(2) But let me just mention it in passing that about four days ago, I made a plea to President Xi Jinping that if they have the vaccine, can they allow us to be one of the first or if it is needed, if we have to buy it, that we will be granted credit so that we can normalize as fast as possible.

$>>$ giving possibility or stating condition

In the example above, the 'if- clause' trigger presupposes that the information is contrary to the reality. Example 1 presupposes that the speaker is uttering a contradictory statement to the reality. It is triggered by the if-clause by stating two opposite ideas. In example (2), the speaker stated a condition to show choices to the listeners and presupposition was triggered by the verb plea. In this research, counterfactual presupposition is the least among the other types. It was not utilized much in the SONA.

\section{Structural Presupposition}

In structural presupposition, certain sentence structures are analyzed as conventionally and regularly presupposing that part of the structure is assumed to be true. This presupposition is triggered with cleft construction, it-clefts, Wh-question, wh-cleft, adverbial clauses, comparative construction, counterfactual conditionals, and nonrestrictive clauses (Yule, 1996).

\section{Excerpts:}

(1) We need men of integrity and faith like Rizal and del Pilar, men of action like Bonifacio, men of inflexible patriotism like Mabini. We need their zeal, their selfreliance, their capacity for work, their devotion to service, their ability to lose themselves in the common cause of building a nation.

$>$ statement of comparison, triggered by the adjective "like"

(2) When the pandemic struck, I decided to prioritize life over other considerations. According to experts, the interventions that the government had put in place prevented as much as 1.3 to 3.5 million infections. To me, even if the numbers were much lower, it would still be and would have been worth the sacrifice[s] we made. -Buhay muna, bago ang lahat." [applause]

$>>$ stating a situation triggered by adverbial clause

In the example (2), adverbial clause is used as adverbials main clause. It is triggered by the pronoun "when". According to Biber et al. (1999) these clauses have some freedom of positioning. They are commonly placed either in initial or final position. Karttunen (cited in Levinson, 1983) emphasized that comparisons and contrasts in sentence structure, triggers presupposition. In the above example (1) the comparative construction "like" which is an adjective, signals the trigger of presupposition.

\section{Non-factive Presupposition}

Non-factive verbs such as 'dream', 'imagine' and 'pretend' presupposes that the propositions are 'untrue' (Yule, 1996).

\section{Excerpts:}

(1) We live in a troubled time. Our dream of prosperity for our country was suddenly snuffed by a pandemic virulent virus. No nation was spared. Neither rich nor poor were exempt from the onslaught of this deadly disease.

$>>$ an utterance of dream, hope and wish for the country 
(2) In 2021, we aim to increase access to healthcare services by continuously hiring and deploying more than 20,000 health professionals. This will augment health workforce in the LGUs, particularly in isolated and disadvantaged areas. We will implement projects

to establish and improve Barangay Health Stations, Rural Health Units, and other healthcare facilities.

$>>$ speaks about future goals for the upcoming year

In the given example (1), the speaker uttered his wishes for his country. It is triggered by saying the pronoun "our" which is attached to the noun "dream". This presupposes that the speaker is dreaming for the country to be spared from the coronavirus, but he added that the nation is not exempted. Thus, expression of dream presupposes that it is untrue or cannot be permitted for a period of time. Likewise, example (2) is also an expression of "dream". It presupposes the speaker's future goals for the country's current situation.

\section{Political functions of Presupposition in SONA}

It is found out that the most frequently used presupposition in this study is the lexical presupposition which occurred 87 times out of 199 paragraphs. The presupposition triggers found are verbs of judging, iteratives, and implicative verbs. One example of verbs of judging from the data is - "Obviously, he was defending the Lopezes that they are not oligarchs." According to Fillmore (1969), verbs of judging involve blaming, accusing, and criticizing. Fillmore explained that accuse when we agree the situation is bad and want to assign blame or responsibility; while criticize when we know who was responsible and want to give a value judgement. Another example of lexical presupposition is the iteratives - "And this one, I strongly urge Congress to pass a law establishing the Department of Overseas Filipinos [focused] solely on addressing the concerns of Filipinos abroad and their families. I reiterate the swift passage - before that - before this... Kawawa kasi itong ating mga overseas. (The Overseas Filipino Workers are pitiful). If it's only an office there in the Labor department they are overworked or for whatever reason, their needs, their pleas are not really attended to with dispatch and with care. OFW pati itong ano ngayon ito yung sinabi ko kanina, (this is the one that I've been telling earlier) they - I... I will go for it. We will need it to help them." The Presupposition theory of Yule (1996) emphasized that iterative lexical technique is based on the repetitive application of regular expressions. Meanwhile, for implicative verbs, one of the examples is - "Rest assured that we will not dodge our obligation to fight for human rights." This statement implies that the speaker wanted to express that he can manage the obligation at hand. Implicative verbs entail their complement clauses that begin with the complementizer "that". Based on the results of presupposition found in the SONA, it can be argued that the abundant use of presupposition triggers helps to better communicate the politician's political messages and consequently grip their audiences through a strategy that may be used to express a speaker's socio- political dominance (Peter et al., 2016).

According to Liang and Liu (2016), presupposition triggers especially lexical presupposition, play an essential role in delivering strong information to the audience, putting utterances in an intense manner, motivating, and establishing good interaction with the audience through affirmation that he or she will manage the nation can draw a closer relationship between the speaker and the audience. Some examples of that are presented in statements 1 and 2. The speaker affirmatively stated that he would manage and assure the nation about his duties and responsibilities.

In addition, VanDijk (1996, p.34) described that "syntactic variation, such as word order, usually has two types of political functions, viz., that of emphasis or mitigation through more or less prominent placement of words and phrases, and the ways underlying semantic roles are focused on". It is found in this study that lexical presupposition was the 
mostly used presupposition because of too much emphasis in the word order of President Duterte. Some of these are maximizing the use of the phrases -

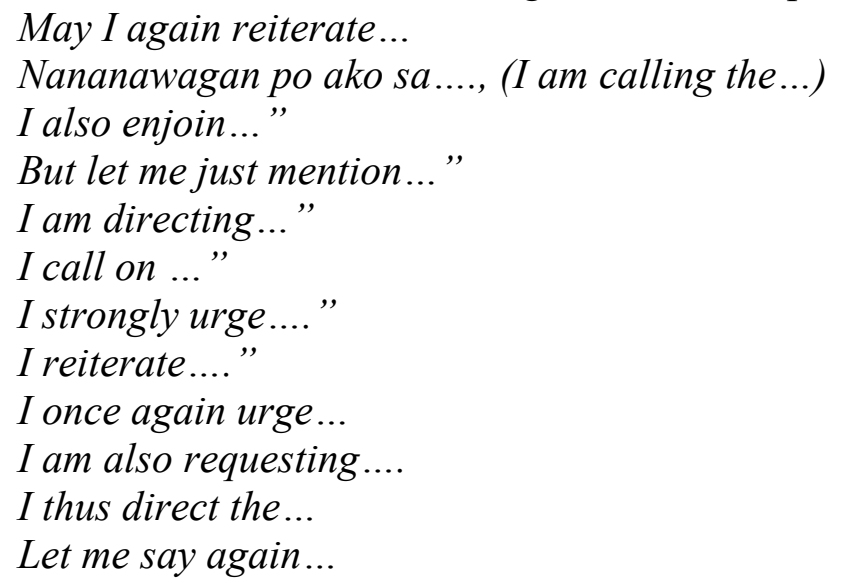

The phrases above were mostly presented at the later part of his speech. Hence, these are indirectly parallel to semantic stress on specific meanings, which contribute as a function of the political interests and adherences of the speaker (VanDijk, 1996). Among the presupposition types, Yule (1996) categorizes this as iterative verbs. These are frequentative in form and used to emphasize a certain proposition.

Furthermore, rhetorical function is also recognizable in the SONA. One of the major strategies of this is to entice attention and to enhance construction of meanings in mental models, memorization, persuasion attempts, and recall (Allen 1991; Cacioppo \& Petty 1979; Frédéric 1985; Johnstone 1994, cited in VanDijk, 1996). According to Pedersen (n.d.) in the field of politics, rhetorical function happens when the politicians focus on his argumentation for his position and breaking down the credibility of the opponent. Listeners can recall that in the SONA, the speaker mentioned Senator Franklin Drilon's statements from an interview. Excerpts:

(1) One of them is Senator Frank Drilon. In an interview, he arrogantly mentioned among others that oligarchs need not be rich. Then he linked the anti-dynasty system with oligarchy and the topic was my daughter and son. This happened after the Committee on Franchise voted 70-11 to deny the grant of franchise to ABS-CBN. Obviously, he was defending the Lopezes that they are not oligarchs.

(2) Kayong may pera, $p^{* * *}$. May pera kayo? Negosyo kayo. Wala kayong pera? $P^{* * *}$, umalis kayo dito. (Those of you who have lot of money $p^{* * * *}$. You got money? You don't have money? $P^{* * *}$, move away from here.) You know, you give us half deals, half-cooked transactions, lousy service. Tapos ang tao nagbabayad. (Then people will pay.)

(3) You know Drilon, stand it - he was defending... I would like to ask Drilon, were you a part of ACCRA when this contract of Ayala water was being drafted?

(4) But ito (here), to my countrymen, the oligarchy that exists in this country is the oligarchy that existed during the Spanish time. And the Spanish lands and the friar lands and all the benefits that were passed on to the Insulares who did not go back to Spain or to the Spaniards and into their... But that was long ago, it has been forgotten. This is the oligarchy that controls the Philippines by what? By taking control of the water and the electricity and power. Iyan ang oligarchy mo Drilon (That is your oligarchy, Drilon) [applause]

In the given statements above, verbs of judging were conveyed, and these are examples of lexical presupposition. Fillmore (1969) mentioned that a verb of judging describes the events of communication. Verbs, such as, accuse, criticize, praise, scold, confess, apologize, necessarily describe a communicative act (not necessarily spoken), and 
others can just relate to internal attitudes like blame, credit, justify, and excuse. In addition, excerpt 2 above shows vulgar words and profanity, an example of verbs of judging such as accuse and scold (Fillmore, 1969). These findings are similar to the analysis of Teehankee and Thompson (2016), and Szilágyi and Thompson (2016), which they concluded that President Duterte uses expletives and offensive and vulgar types of communication when communicating to foreigners, and government officials.

Expression structures also existed in the SONA of President Duterte. This is about the volume (shouting and whispering), pitch and intonation of speakers. Preferred meanings are thus emphasized by shouting, high pitch, raising intonation. An example of this is found in the excerpt below

“...That is the reason why I'm so vicious in my - galit talaga ako kasi nilalaruan tayo (I am really angry because they are toying us). Well, I don't know any other president might - pero ako ayaw koyon (but I don't like that). Ayaw kong lalaruan ang Pilipino. (I don't like them to make Filipinos as toys). Do not do it in my country because I will really kill you. That is a commitment."

Apparently, the supra-segmental aspect of the statement in the given example clearly shows that the speaker is angry. The tone, stress, intonation, and choices of words really show his irate emotions while delivering those propositions. Suprasegmental is also called a prosodic feature, and prosody may reflect various features of the speaker or the utterance. It could be in the emotional state of the speaker, and through the presence of irony, emphasis, contrast, or focus (Bittner, 2013).

The last political function of presupposition found in the SONA is racism. Van Dijk (1996) expounded that racism is considered as a political function that is usually exhibited in language. Here is an example.

“... I have nothing against America, I have nothing against China but if you put bases here, you will double the spectacle of a most destructive thing just like Manila during the Second World War ..."

Van Dijk (1996) explained racism as a system of social inequality that implies that social groups do not have equal access to and control over material and immaterial social resources. He also added that racism develops and increases where extreme inequality, and oppression exist--in particular where structures of inequality overlap with differences of color or origin. In the given example above, the proposition portrays differences between America and China, in which the speaker further explained that a visual situation like the Second World War in Manila may strike when President Duterte said the term "you will double the spectacle of a most destructive thing". The example above is called apparent negation and apparent concession.

President Duterte highlighted that is not anti-US or anti-China, but he implicitly informed the listeners that they should not look at him as an opponent of the two countries to avoid conflict.

Moreover, promises were also prompted in the SONA. Thompson (2016) elaborated in his study that Duterte's previous speeches were full of promising propositions through the expression of his goal on war on drugs. Likewise, in his $5^{\text {th }}$ SONA, he reiterated many times his propaganda about the war on drugs. Promises are related to the use or lexical presupposition such as "managed", "tried", "start", and "succeeded". Yule (1996) pointed to an example like "when someone says that he "managed' to do something, the asserted meaning is that the person succeeded in some way. So 'managed' is conventionally interpreted as asserting 'succeeded', and presupposing 'tried'. Below are examples.

Excerpts: 
(1) I reiterate the swift passage of a law reviving the death penalty [applause] by lethal injection for crimes specified under the Comprehensive Dangerous [Drugs] Act of 2002.

(2) Hindi ngayon. (Not now) But when I ' $m$ - sasabihin ko sa inyo ang totoo bakit nagkaganito 'yung droga ng Pilipinas. (I will tell you the truth why drugs are like this in the Philippines) Why the drug syndicates continue to operate just like the countries of Colombia, Mexico, and it is being played inside the national penitentiaries. Para tayong - talagang binababoy tayo. Sabihin ko sa inyo. (Let me tell you, they are making us dirty.) But this is not a time for storytelling. SONA kasi ito so dito na lang. (Because this is a SONA).

(3) This law will not only help us deter criminality but also save our children from the dangers posed by illegal and dangerous drugs.

The type of presupposition (lexical) illustrated in the excerpts above can lead the listeners to believe that President Duterte is able to manage his war on drugs propaganda. He may lead the people to necessarily believe on his proposition because of indicating his goal on abrupt passage of the law regarding the death penalty.

In summary, it can be highlighted that President Duterte's speech has a strong pronouncement that might lead to irony among listeners. This communication style is similar to the study of Utari (2017) in which he found out that speeches of President Duterte consisted of rhetorical text that employed metaphoric expressions that are hard to understand by the listeners. Additionally, Teehankee and Thompson (2016) previously explained that the use of expletives is very usual in the speaking style of Duterte.

The presupposition triggers that were found in this study may help the Filipinos to understand further the meaning behind the speaker's utterances. Linguistic features such as lexical presuppositions were shown several times in the speech. Some of these triggers are verbs of judging, iteratives, praise, accuse, and criticism.

Political functions such as apparent negation, apparent concession, and racism existed too in the speech. These were determined in the syntactic structures of sentences through word order or the use of active or passive illustration. The different propositions that were analyzed in this research will indeed assist the readers to juxtapose the text and the intended meaning of the speaker towards his listeners.

Moreover, it was observed that the pronoun "I" was used several times in the SONA. Due to limited time, this aspect was not analyzed in this paper. The pronoun $I$ is used when the speaker wants to speak as an individual rather than as a representative of a group. The functions of pronoun $I$ can be divided into several types such as to express a speaker's opinion, to describe a speaker in a positive image, to create relationship with audiences, to show personal involvement or commitment, and to show a speaker's authority. As mentioned by Brown and Gilman (1960, cited in Kaewrungruang \& Yaoharee, 2018) there is asymmetrical power relations through the choices of pronouns in political discourse, and one of these concepts is the power of the pronoun $I$ in political speeches. Also, Zheni (2019) stated that the pronoun 'I' refers to the role played by the speaker, and expressed through its variants - my, me, and myself. Zheni concluded that person deixis (pronoun I) indicates an image on how communicators establish their world towards the hearers, because using pronoun 'I' leads to an impression that the speaker value his personal space. She called this as "egocentricity, a concept that defines the speaker as the deictic center around whom everything revolves. Thus, personal pronouns are biased political pronouns in political discourse" (p.169). Moreover, nominalization strategy was also found in the study of Utari (2017) when he analyzed the previous speeches of President Duterte. Likewise, it has been observed in this present study that excessive use of pronoun $I$ in the SONA led to expression 
of promises and explained when he stated that one element of nominalization is expression of aims and prejudices.

Meanwhile, this study classifies the speech of President Duterte as rhetoric. Rhetorical devices are usually used in the field of public speaking and these provide powerful tricks in communication. The repetition of words or phrases at the beginning of every clause, the use of ellipsis, and the use of figure of speech (specifically metaphors), made the speech of Duterte rhetorical in context. Using rhetorical devices in public speeches is a technique that incites a responsive reaction to a particular situation. It is a linguistic tool that employs constructive arguments which persuade the listeners. These could be the reasons why the SONA of President Duterte expressed informal style through repetition of personal pronouns, repeated usage of lexical presuppositions such as verbs of judging and iteratives. Duterte's discourse displayed a strong conviction of being nationalist. His speech certainly expressed his overflowing concerns for the Filipinos. However, his way of communication is uncertain at times, especially when he carefully sugar quote his comments about China. Thompson (2016) called this stance as rhetorical switching of sides.

This study found out that Duterte's speech is intertwined to rhetorical strategies of speaking through the use of presuppositions. When he used nouns that carry conventional meaning as lexical presupposition, to establish his proposition about China, his manner of speaking exhibited rhetorical style.

"China is claiming it. We are claiming it. China has the arms, we do not have it. So, it is simple as that. They are in possession of the property. It will remain a property of a - if you're a lawyer, property rights".

The verb claiming in the excerpt above, indicates awareness, realization, and certainty that trigger the proposition to be a factive presupposition. According to Zheni (2017) factive presupposition may also begin with noun phrases (NP). When speaker presents his personal beliefs as factual information, it is more convincing when he uses nouns as the topic to show certainty of propositions. These nouns are 'fact', 'reality', 'truth' and 'certainty' that serve as markers of strong epistemic claims. Rhetorical style of speaking is imbedded on the manner of speaker's persuasive approach. However, the meaning of the statement above is vague when Duterte said "It will remain a property of a - if you're a lawyer, property rights". Hearers may ask about the clear context of his sentiment here. A reason that may bring the public into confusion, especially when he highlighted that only lawyer could understand what he meant.

Furthermore, his direct message (existential presupposition) to individuals, government officials or institutions, in which he associated them into a certain representation also led to rhetorical in form. His tough and colloquial choices of words made it rhetoric, especially when he said:

"The profiteers, over-pricers and corrupt felons must be laughing while they stash their dirty monies. But not for long. They cannot outrun the long arm of the law. In this regard, the words of former President Ramon Magsaysay ring fresh and relevant today as on the day they were said decades ago. He said: We need men of integrity and faith like Rizal and del Pilar, men of action like Bonifacio, men of inflexible patriotism like Mabini. We need their zeal, their self-reliance, their capacity for work, their devotion to service, their ability to lose themselves in the common cause of building a nation".

In the excerpt above, President Duterte used words such as felons and monies, terms that are not usually heard by the Filipino community. His proposition entails that the nation is in need of upright government officials like the Philippine heroes (Rizal, Del Pilar, Bonifacio) to reprimand the violators of the Philippine law.

His message of criticisms and statement of compliments (lexical presuppositions) also portrayed rhetorical context, because of a discordant effect to audiences. 
(1) Iyan ang mahirap sa... (That's the difficult thing with...) You do not protect the oligarchs here. You are the one. Ikaw lang mag-isa. (You are the only one). And I suspect that you were also the one - or helped when you were there in the ACCRA.

(2) "We commend the initiative and work of Senator Bong Go in this regard as well as other significant pieces of legislation."

President Duterte's proposition in excerpt 1 indicates resentment, while excerpt 2 shows appreciation. President Duterte used repeated words to express a strong emotion by revealing his personal opinion and feelings in excerpt 1 . Despite his resilient reaction on some issues in the country, he managed to phrase some individuals and institutions to show his contentment and satisfaction with their roles, and one of this is Senator Bong Go, who serves as his confidant most of the time.

\section{CONCLUSION}

In view of the analysis of presupposition triggers in the speech, the results demonstrated that 'lexical' presupposition triggers language used the most in the SONA, and least used is the counterfactual presupposition. On the basis of the study findings, the following implications can be drawn: (a) presupposition triggers may help politicians to express their goals and aims through lexical presupposition. c.) they are used by politicians to set the background of their negotiation for better and effective communication through the use of factive and structural presuppositions. (c) presupposition triggers may help politicians to make his speech directed to a specific individual or institution to call for an attention for his criticism, acknowledgement, and admiration through the use of existential presupposition. Hence, the four mentioned presuppositions (lexical, factive, structural, and existential) are the top 4 most frequently used presuppositions in the $5^{\text {th }}$ SONA of President Duterte.

Speech is a public discourse and has a bulk of presupposition, it is therefore necessary for the audiences or listeners to have good knowledge of presupposition in order to get good interpretation. The use of presupposition triggers help to better communicate the message of a community leader to grab audience attention. However, one must take note that behind a political speech, there are societal functions that one must understand. As recapitulated in this study, President Duterte's speeches are usually straightforward and filled with profanity, thus, lack finesse; so for people to understand what he was saying, they should be able to relate and connect the intertextual reference with the context. Context helps establish meaning and can influence what is said and how it is said. Hence, cultural (mis)understanding depends on an individual's ability to (dis)associate and relate with others; the hearer or listener can create his/her own understanding of the "others", in the same way they may be (un)consciously perceived through one's cultural glasses (Gullestrup, 2006). Presuppositions somehow helped Duterte's communicative style to catch audience's attention, but many of his propositions are elliptical, ambiguous, colloquial, and implicit. Thus, these factors made his speech rhetoric in form, a political function or discourse that was coined by VanDijk (1996). In relation to this, people must understand that culture and communication are intertwined, and culture are based on symbols which help us to share and understand the meanings of one's behavior. When we are communicating with people from other cultures, it is important to understand the codes of their own symbols. President Duterte has his codes based on his own culture which so often does not translate very well to those outside of his circle with a different code of politeness; it is inevitable that they find the content and manner of his speech highly ambiguous, disdainful and unacceptable. The disconnection with the "other" group of Filipino audience only demonstrates his failed attempt in delivering his political message, hence, a failed rhetoric.

Therefore, based on the given conclusions, the following recommendations have been made for future research endeavors. First, the intercultural communication lens must be 
considered to deepen one's understanding towards the cultural symbols or codes of President Duterte's language. Second, explore more on the excessive use of pronoun $I$ in President Duterte's political speeches. Third, compare and contrast all the speeches of President Duterte to further analyze the common linguistic features used in his political speeches. Lastly, future researchers may look into the insights of the listeners to know their personal interpretation about the political speeches of Duterte.

This study of presuppositions in SONA hopes to contribute to the composition of better understanding of political speeches in the Philippines and beyond.

\section{REFERENCES}

AL-Smaihyeen, M., \& Abdul Latiff, M. (2018). Pragmatic Approach: Lexical Presupposition in King Abdullah II Political Speech. Journal of Social Sciences (COES\&RJ-JSS). 7 (4), pp.358-365. Retrieved from: https://doi.org/10.25255/jss.2018.7.4.358.365

Al-Zubeiry, H.Y., (2020). Presupposition Triggers in British and Saudi English Newspaper Opinions. Theory and Practice in Language Studies, 10 (7), pp.734-743. Retrieved from: http://dx.doi.org/10.17507/tpls.1007.03

Balogun, S. (2018). Language in political discourse: A Pragmatic study of Presupposition and Politeness in the Inaugural Speech of President Donald Trump. Bulletin of Advanced English Studies, 1(1), pp.64-76. Retrieved from http:// www.refaad.com

Biber, D., Johansson, S., Leech, G., Conrad, S. \& Finegan, E. (1999). Longman Grammar of Spoken and Written English. London: Longman.

Bittner, M. A. (2013). Prosody and Suprasegmental Features. Retrieved from https://www.academia.edu/5330576/Prosody_and_Suprasegmental_Features

Cheng, M. (2002). The Standoff - what is unsaid? A pragmatic analysis of the conditional marker 'if'. Discourse and Society. SAGE Publication 13 (3), pp. 309-317

Creswell, J.W. (2007). Qualitative inquiry and research design: Choosing among five approaches (2nd ed.). Thousand Oaks, CA: Sage.

Fillmore, C. J. (1971). Types of Lexical Information. In F. Kiefer, ed., Studies in Syntax and Semantics. Foundations of Language (Supplementary Series), (10), pp. 109-137. Dordrecht: Springer.

Fillmore, C. J., \& Langendoen, D. T. (1971). Studies in linguistic semantics. New York: Holt, Rinehart \& Winston.

Ge, L. (2011). Pragmatic Functions of Presupposition in Advertising. English Asian Culture and History. 3(1), pp. 153-157. China: Henan Retrieved from: www.ccsenet.org/ach

Gullestrup, H. (2006). Cultural analysis towards cross-cultural understanding. Denmark: Aalborg University Press

Kaewrungruang, K. \& Yaoharee, O. (2018). The Use of Personal Pronoun in Political Discourse: A Case Study of the Final 2016 United States Presidential Election Debate. Sola Reflection, 25 (1) pp. 85-96. Retrieved from https://files.eric.ed.gov/fulltext/EJ1271188.pdf 
Karttunen, L. (n. d.) Presuppositional phenomena. In Levinson, S., C. (1983) Pragmatics. Cambridge: Cambridge University Press

Kroeger, P. R. (2018). Analyzing meaning: An introduction to semantics and pragmatics. Berlin: Language Science Press.

Levinson, S. C. (1983). Pragmatics. Cambridge: Cambridge University Press.

Liang, R. \& Liu, Y., (2016). An Analysis of Presupposition Triggers in Hilary

Clinton's First Campaign Speech. International Journal of English Linguistics. 6(5), pp. 68 - 73. Canadian Center of Science and Education

Merriam, S. B. (2009). Qualitative Research: A Guide to Design and Implementation. San Francisco, CA: Jossey-Bass

Pedersen, H. S. (n.d). Rhetorical functions and ethics of narratives in political speeches. Retrieved from: https://silo.tips/download/rhetorical-functions-and-ethicsof-narratives in-political-speeches

Peter, C. A., Mukuthuria, M., \& Muriungi, P. (2016). The Use of Presupposition in the Creation of Socio- Political Dominance in Kenyan Parliamentary Debates between 1992 and 2010. Journal of Education and Practice, 7 (24), pp. 154-172. Retrieved from www.iiste.org

Utari, N. (2017). A Political Discourse Analysis on Rodrigo ROA Duterte's Drug War Policy. Universitas Islam Negeri. from https://core.ac.uk/download/pdf/157583617.pdf

Van Dijk, T. A. (1989). Social Cognition and discourse. In H. Giles \& R.P. Robinson (Eds.). Handbook of social psychology and language (pp. 163-183). Chichester: Wiley

Van Dijk, T. A. (1996). Discourse, power and access. In C. R. Caldas-Coulthard \&

M. Coulthard (Eds.). Texts and Practices. Readings in critical discourse analysis (pp. 84-104). London: Routledge.

Van Dijk, T. A. (2005). Politics, ideology and discourse. In R. Wodak (Ed.). Elsevier

Encyclopedia of Language and Linguistics. Volume on Politics and Language (pp. 728-740). Spain: Elsevier Ltd.

Widdowson, H. G. (2004). Text, context, pretext: Critical issues in discourse analysis. Oxford, UK: Blackwell Publishing

Yule, G. (1996). Pragmatics. Oxford: Oxford University Press

Zheni, T. (2017). A Socio-cognitive Approach to Factive Presupposition and Epistemic Modality in Hillary Clinton's Political Discourse: Tunisia's Democratic Transition as a Case Study. English Department, Faculty of Letters, Arts and Humanities, Manouba University, Tunisia (Ph.D.'s Thesis). Retrieved from Arab World English Journal Database. DOI: ://dx.doi.org/10.24093/awej/th.2002 
Zheni, T. (2019). Factive vs. Ideological Knowledge in Political Discourse. International Journal of English Linguistics, 9 (1) pp. 36 - 53. Canadian Center of Science and Education. https://doi.org/10.5539/ijel.v9n1p36

Zheni, T. (2019). Person Deixis as Biased Political Pronouns in George W. Bush's Speeches on Iraqi War II. International Journal of Language and Literary Studies, 2 (1) pp. 155 - 171. https://doi.org/10.36892/ijlls.v2i1.112

Zheni, T. (2020). Speech Acts and Hegemony in Discourse: Donald Trump's Tweets on the US-Iranian Nuclear Crisis. International Journal of Language and Literary Studies, 2 (4) pp. 215-235. https://doi.org/10.36892/ijlls.v2i2.283

\section{AUTHORS' BIO}

Mary Ann Murillo is an adjunct lecturer at the Center for General Education Department, AMA International University in Bahrain. She received her MA in Teaching English from De La Salle University - Dasmariñas, Cavite, Philippines, and currently finishing her PhD in Language Studies through distance learning in the same University.

Dr. Aiden Yeh is an Associate Professor at Wenzao Ursuline University of Languages, Taiwan. She received her PhD in Applied Linguistics from the University of Birmingham, $U K$, and her MSc in ELT Management from the University of Surrey, UK. 